\title{
LESSONS LEARNED FROM THE EFFECT OF TIGHT MONETARY CONDITIONS AND CRISES ON CORPORATE CAPITAL STRUCTURE
}

The study reviews the theoretical and empirical literature on the effect of tight monetary conditions, crisis on corporate capital structure, further creates a framework for analyzing their relation, as well as sheds light on the lessons learned and open research areas.

The results highlight that the supply side of capital has an effect on corporate capital structure, though the analysis of this relation is scarce. However, the impact of tight monetary conditions on capital structure is analyzed by several studies, there is limited evidence on the financial policy and the development of financing mix during a crisis period. The impact of the $2007 / 08$ crisis on the corporate capital structure and especially in case of firms with impaired access to external financing is scarce. The study also highlights our lack in understanding of the relation of crisis and capital structure in case of the CEE region.

Keywords: tight monetary conditions, crisis, capital structure, impaired access to financing

Based on the seminal work of Modigliani and Miller, the search for optimal capital structure generated several theories (e.g. trade-off theory, signalling, agency costs theory). In spite of the plentiful empirical testings and new theories (e.g. financial flexibility), there does not seem to be any single, universal, and empirically validable capital structure theory.

Apart from the research collected to date, some new research aspects are arising; one of these new aspects determines and measures the role of supply factors in capital structure movements, dissolving MM's assumption of the supply side's perfect elasticity (e.g. Faulkender - Petersen, 2006; Becker, 2007; Ivashina Scharfstein, 2008; Akbar - Rehman - Ormrod, 2013; Lemmon - Roberts, 2010; Leary, 2009; Duchin - Ozbas - Sensoy, 2010; Voutsinas - Werner, 2011).

However, to measure the exact effect of supply factors on capital structure, a clean differentiation of supply and demand factors is needed. Tight monetary conditions and crisis - assuming these represent supply shock to the capital markets - offer an opportunity to measure the supply side effect of capital markets on corporate capital structure.

After introducing the tight monetary conditions and highlighting the macro environment of the 2007/08 crisis, this study develops a theoretical framework for analyzing the effect of supply factors on the basis of the works of Gertler and Gilchrist (1993), Gertler and Gilchrist (1994), Oliner and Rudebusch (1995), Bernanke, Gertler and Gilchrist (1996), Kashyap, Stein and Wilcox (1993), and Kashyap and Stein (2000). By means of the framework, identification of expected capital structure movements as a result of tight monetary conditions and crises takes place. Further, empirical results on the effect of supply shocks and crises on capital structure are reviewed in order to identify the lessons learned and open research areas. The study also focuses on the CEE region, investigating what kind of effect the region's uniqueness exerts on capital structure movements during the crises. Although the CEE region shows a unique development and status, mainly due to the transition process in 1989-91, there are limited findings for the region in the topic investigated.

According to Colombo (2001), the transition process resulted, that the size of the region's capital markets and their late progress make the general use of some external sources not possible; trade credit is commonly used owing to the past plan economy; the ownership structure may be a significant determinant of capital structure. Considering the severity of the impact of the 
2007/08 crises in the CEE region, domestic loans granted in foreign currencies should get taken into account (mainly in Euros or Swiss francs due to the low interest rates). The remarkable share of this financing type became a heavy burden for borrowers by currency depreciation during the crises.

\section{Definition of tight monetary conditions and the 2007/08 crisis}

Monetary policy deals with the management of a nation's economic activity with the main goal of regulating the inflation movements within the economy. Monetary tools most widely used are the setting of discount and prime interest rates for lending money in the open market and the regulation of the money supply available in the given economy. A restrictive policy can be managed through the tightening of credit qualifications, soaking up the cash surplus of the markets and/ or raising the banks' reserve requirements. Either way, tight monetary conditions may result in a decrease of credit supply.

The 2007/08 crisis, originated from the subprime crisis in the US market, created a shock to the markets (e.g. Brunnermeier, 2009). The crisis exerted a massive negative effect on the basis of all financial systems; trust started to vanish from the markets in 2007 as banks started questioning the viability of their counterparties. By the collapse of Lehmann Brothers in September 2008, trust on the global financial markets dissolved; trust in bank counterparties, trust in the overall stability of the financial system, and also the systemic trust in the financial institutions started to vanish.

GDP growth rate (Source: World Bank)

Figure 1

The annual percentage growth rate of GDP at market prices based on constant local currency

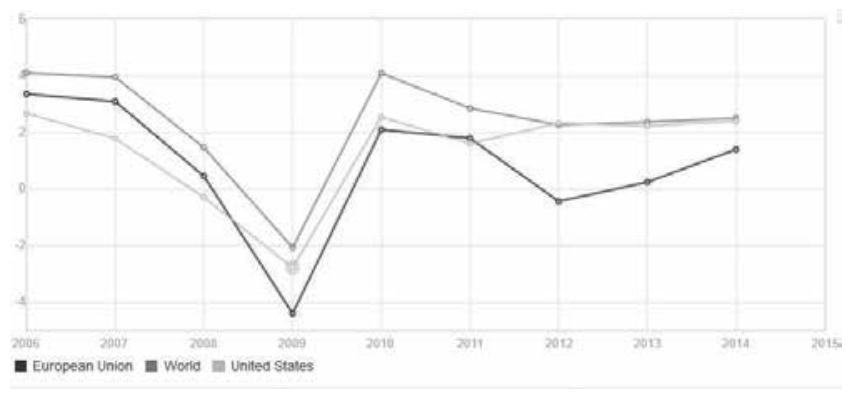

Although, at the same time the macroconditions worsened. While the period before the crisis is characterized by a high global growth and stable inflation globally, in the EU and USA, the crisis brought a slow- down in GDP growth rate (below $2 \%$ global growth rate in 2008 compared to $3,8 \%$ in 2007) and increased inflationary pressures (reaching above $8 \%$ globally in 2008 based on World Bank data). Moreover, the reduction of monetary policy rates were used in many countries under the monetary actions taken in 2007/08; (find Figures 1-3).

Figure 2

Inflation, consumer prices (Source: World Bank)

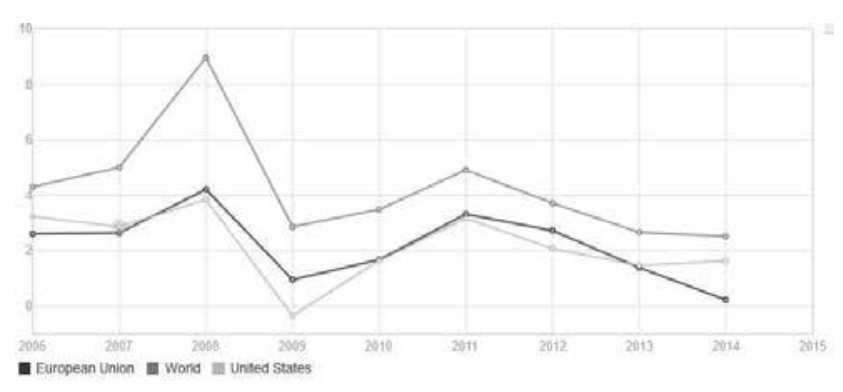

Figure 3

ECB and FED policy rate

(Source: European Central Bank, Statistical Data

Warehouse, https://www.ecb.europa.eu/mopo/ implement/omo/html/top_history.en.html; Federal

Reserve Bank of New York, Federal Funds Data

Historical Search, https://apps.newyorkfed.org/ markets/autorates/fed-funds-search-page)

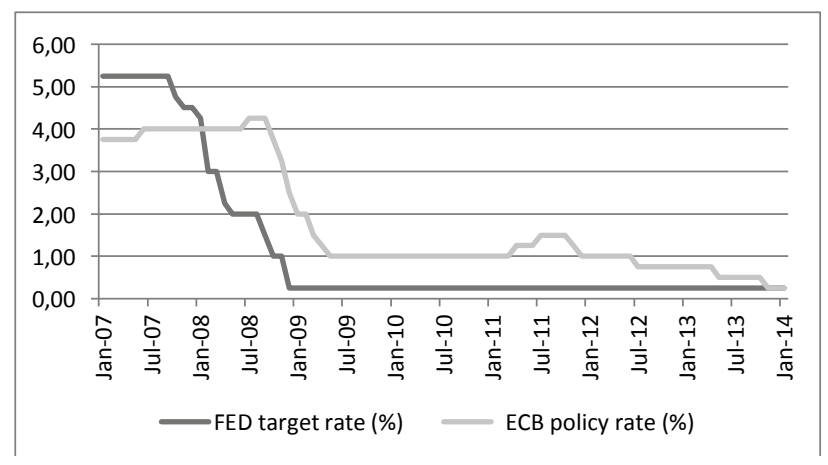

Hence, the corporate sector had to face the severe effects of the dissolving trust and the worsening macroconditions simultaneously. As a result, there is an observable and measurable impact of the global financial crisis on corporate capital structure, although, in spite of the research results to date, we do not have a clear picture about the course and scale of the evolution of capital structure components (i.e. leverage and financing mix elements). In addition, the need for clean results in the case of companies with impaired access to external financing and for the CEE region is obvious. 


\section{Theoretical framework for analyzing the supply effect on capital structure}

\section{Factors influencing capital structure in tight monetary conditions and crisis}

The investigation of monetary policy's effect on the real economy has already been subject to the work of Tobin and Brainard (1963), though the relation was stated only later by Romer and Romer (1989), Bernanke and Blinder (1988 and 1990).

According to the basic idea of the monetary transmission mechanism, tight monetary policy influences the passiva side of banks, decreasing the amount of money flowing in the bank system (money channel). Alternatively, monetary policy measures affect the real economy by means of altering the lending activity of banks, partially through decreasing the supply of credit (lending channel).

Early studies investigated the transmission mechanism of the lending channel (Blinder - Stiglitz, 1983; Romer - Romer, 1989; Bernanke - Blinder, 1988; Bernanke - Blinder, 1990). The idea is that unfavourable changes in the monetary policy have an impact on banks' fund collecting activity, indirectly affecting the lending activity (bank lending channel). Kashyap, Stein and Wilcox (1993) emphasize that the unfavorable change in the monetary policy generates a greater decrease in supply of bank lending than in the case of the overall supply of credit, resulting in a lack of finance for some corporates.

Questioning the results of Kashyap, Stein and Wilcox (1993), Oliner and Rudebusch (1995) and Gertler and Gilchrist (1994) emphasize the transmitting role of credit supply in a broader sense, considering every financing possibility as a source of supply (broad lending channel). Considering the possible financing sources, Oliner and Rudebusch (1995) describe that, based on the existence of information asymmetries, external and internal sources are not perfect substitutes. Furthermore, there is a premium on the price of external sources; its value correlates with the tightening of monetary policy. The tighter the monetary policy is, the higher the premium and so is the price of external funding, possibly resulting in the fall of supply.

Further studies investigated the impact of monetary policy on corporate financing from various aspects of the broad lending channel.

In the following, the main points of the considerable works of Gertler and Gilchrist (1994), Khwaja and Mian (2008), Kahle and Stulz (2013) are reviewed.

According to Gertler and Gilchrist (1994), the financial factors, resulting from capital market imperfections, transmit the capital markets' shocks to the real economy in tight monetary periods through two chan- nels. The balance sheet view declares that a corporate's wealth and assets determine its lending possibilities serving as collateral for external financing. Then, monetary policy affects the company in two ways. Its direct effect can be captured through the change of monetary instruments (e.g. interest rate), while monetary policy can also have an indirect effect by altering the demand for the company's products. Unfavorable changes in monetary policy decrease the cash flow and asset value of the company, resulting in lower capital supply.

In the credit/lending view, monetary policy determines the funds available for lenders by means of, for example, capital requirements, which has an effect on credit available for corporates.

Khwaja and Mian (2008) investigated the impact of a bank liquidity crisis on the economy. They identified two distinct channels, through which a liquidity crisis takes its effect. Through the bank lending channel liquidity shocks are passed over to borrowers by means of credit supply conditions as quantity and pricing parameters, even if the borrowers' parameters, such as credit rating, are unchanged (Kashyap - Stein - Wilcox, 1993; Kashyap - Stein, 2000; Paravisini, 2007). The borrowing channel represents the availability and use of alternative financing sources to bank credit. The channel gains in importance in the case of decreasing bank credit supply.

According to Kahle and Stulz (2013), impaired access to capital takes its effect on the capital structure of companies through four different channels in case of crisis. The bank lending supply shock describes that in cases of considerable asset losses, banks are forced to regain their healthy balance structure through active and/or passive side operations (that is, mainly through capital increase and/or asset selling). Active side operations taken for the main part are the sale of securities, stocks and bonds, termination of existing loan facilities and freezing of new credit granting. These actions result in a decreasing supply of credit.

The credit supply shock deals with the supply of sources in general, reviews banks and alternative financing sources as well. Due to the increased level of uncertainty and risk, investors are turning away from the credit markets, the level of investment activity is decreasing, and the liquidity vanishing from the markets. Since not only bank lending, but financing sources in general are scarce in case of a credit supply shock, lack of bank financing cannot be substituted by alternative sources.

The demand shock describes that the demand for goods may decrease and uncertainty about future demand may increase during a crisis.

The balance sheet multiplier effect points to the relationship of a company's net worth and its financ- 
ing and investment policy (for a literature review see Brunnermeier - Oehmke, 2012). When asset values decrease, firms have a lower net worth, resulting in less collateral for new borrowings and for renewable loans.

Though all three works describe the impact of monetary policy on corporate capital structure similarly, different mechanisms with differing designation are identified.

Kahle and Stulz (2013) use the broades grouping of mechanism, representing not only the supply, but the demand side as well. The direct balance sheet view of Gertler and Gilchrist (1994) conforms to the demand shock of Kahle and Stulz (2013), and the indirect balance sheet view to the balance sheet multiplier effect. The bank lending supply shock and credit supply shock of Kahle and Stulz (2013) represent Gertler and Gilchrist's (1994) credit/lending view in a more detailed manner. Since Khwaja and Mian (2008) investigate the development of bank lending, their bank lending channel is a tighter category than the credit/lending view of Gertler and Gilchrist (1994). Furthermore, Khwaja and Mian's (2008) bank lending channel acts similarly to the bank lending supply shock of Kahle and Stulz (2013). While Khwaja and Mian (2008) identifies the access to financing sources from a demand view (firm borrowing channel), the credit supply shock of Kahle and Stulz (2013) and the credit/lending view of Gertler and Gilchrist (1994) works with a supply point of view.

In the following sections, the categorization of Kahle and Stulz (2013) is followed mainly due to its very detailed manner and the fact that it best incorporates other categorizations.

\section{Factors influencing capital structure in tight monetary conditions and crises considering access to external financing}

Firm characteristics influence the credit supply and the access to external financing sources of the firm by having an effect on the degree of information asymmetry, agency costs and corporate control mechanism. As a result, firm characteristics have an indirect effect on the firm's capital structure. This effect gains importance in tight monetary conditions, like a crisis, since monetary conditions alter the relation between a firm's characteristics and information asymmetries, agency costs and control mechanism, specifically in the case of firms with impaired access to external financing sources.

Oliner and Rudebusch (1995) state that the more tightening in monetary conditions takes place, the more the relative cost of external financing sources to internal sources rises. Further, firms facing larger information asymmetries are paying larger premium for external sources than firms with lower asymmetries, which results in the former being more prone to mon- etary shocks. According to Bernanke, Gertler and Gilchrist (1996), agency costs of lending are moving parallel with the cyclicality of the economy. Moreover, the greater the information asymmetry, the larger the agency costs of external financing. So in case of unfavorable monetary changes and crisis, the ,flight to quality" phenomena occurs and firms facing higher level of agency costs will be able to borrow less and will suffer from the economic downturn to a relatively larger extent than a borrower with a lower level of agency costs.

In order to get a meaningful and detailed picture of the topic investigated, further analysis distinguishes firms with limited access and with unlimited access to external financing. The aim is to investigate whether tight monetary conditions in a crisis have a different impact on capital structure in case of firms with different access to external financing. In the literature, access to financing is identified mostly by the firm size, the listed status or having a rating. This study takes firm size and the listed status into consideration and is further executed by means of the transmission channels of Kahle and Stulz (2013) as described formerly.

Tighter monetary policy in crisis decreases the supply of credit through the bank lending channel, having a more pronounced effect on firms of a smaller size with less collateral and on firms with higher leverage (Holmström - Tirole, 1996; Hancock - Wilcox, 1998; Berger - Udell, 2002; Becker - Ivashina, 2014). However, according to Khwaja and Mian (2008) the channel transmits impacts of the same intensity on smaller and larger companies. Furthermore, they state that the monetary policy has its effect predominantly through quantity constraints.

Tightening of credit supply in broader sense impacts the smaller bank-dependent firms to a greater extent through the credit supply channel, mainly due to the higher level of information asymmetry and agency costs and due to the fewer alternative financing possibilities of these firms (Bernanke - Gertler - Gilchrist, 1996; Gertler - Gilchrist, 1994; Oliner - Rudebusch, 1995). Based on the results of Khwaja and Mian (2008), the decrease in bank lending could be settled by alternative, non-bank sources in the case of firms of a larger size, with political embedment and/or firms of large holdings. Investigating the financing of listed companies, Bernanke, Gertler and Gilchrist (1996) state that external financing is available for these firms instead of tightening monetary conditions, mainly due to their accessible alternative financing possibilities. Oliner and Rudebusch (1995) state that, based on their results, smaller companies are affected by unfavorable monetary conditions through the credit channel, while the effect cannot be tracked in the case of larger companies.

Furthermore, the decrease in profitability and the increase in default risk is less likely to apply to larger 
companies owing to their higher level of diversification. Thus tighter monetary conditons have less of an impact on the financing possibilities of larger firms through the demand channel.

In monetary tightening, asset values decrease and asset marketability on secondary markets worsens, resulting in a decreasing collateral value of assets. Based on the functioning of the balance sheet multiplier channel, financing is offered to borrowers with higher collateral values, i.e. that of a larger size (Michaelas Chittenden - Poutziouris, 1999).

\section{Expected development of capital structure in tight monetary conditions and crisis}

Supply side capital movements exert influence on corporate finance decisions (i.e. investment, financing and dividend policies) simultaneously. As the focus of this study is on corporate capital structure movements resulting from tightening of monetary conditions and crisis, we concentrate on the development of financing decisions. Investment and dividend policies are analyzed and taken into account to the extent of their influence on the development of leverage and financing mix elements. A more complex analysis on the effect of monetary conditions, crisis on the three corporate finance policies lies beyond the limitations of this study.

Considering the above findings on the transmission channels, we can ask how monetary conditions or crisis are shaping the capital structure. What development of leverage and use of alternative financing sources, what change in the composition of financing mix can be expected as a result of the impact of tighter monetary conditions? Are different developments expected taking corporate characteristics, i.e. access to external financing, into account?

\section{Development of leverage}

Note: The development of leverage should be evaluated with caution. In the case of sudden shocks and rash changes in monetary conditions, and assuming that equity does not change in the precise moment the shock is occurring, the development of leverage purely reflects the change in debt position (e.g. fall of debt level due to cutbacks on credit lines). However, if the impact of a monetary change or crises is to get evaluated based on periodical data, rather than stock data, the effect of possible changes in equity position should be taken into account as well. It is misleading to have the total change in leverage account for the change in debt position during a period, since the equity position could have altered as well.
In tightening and crisis, companies receive less or no bank credit considering the bank lending channel, and thus a decreasing leverage is expected. A more pronounced decrease is expected in the case of smaller, more leveraged firms and/or in case of firms with less collateral (Bernanke - Gertler - Gilchrist, 1996; Gertler - Gilchrist, 1993; Gertler - Gilchrist, 1994; Kashyap - Stein - Wilcox, 1993; Kashyap - Stein, 2000). However leverage is shaped through the availability and quantity of alternative sources to bank credit as well. If sufficient alternative financing to bank credit is available, decreasing bank financing can be substituted with alternative financing, that is, leverage remains unchanged.

If the tightening and crisis have an impact on credit supply in general, then not only the availability of bank credit, but also that of alternative sources are affected through the credit supply channel, decreasing leverage is expected. Firms of a smaller size and bank-dependent ones are suffering from decreasing credit supply, while larger and/or listed companies can outweigh the impact more likely, mainly due to their more financing sources available, e.g. cash and equity-type sources (Bernanke - Gertler - Gilchrist, 1996; Gertler - Gilchrist, 1993; Gertler - Gilchrist, 1994; Kashyap - Stein - Wilcox, 1993; Kashyap - Stein, 2000).

Through the demand channel, a decrease in demand results in vanishing growth opportunities, which leads to a sharp fall in investments. Declining CAPEX requires less financing, both debt- and/or equity-type financing. So leverage remains unchanged or declines. (Taking periodical data, the simultaneous decrease in equity and debt is possible. If equity falls at a greater rate, then debt and leverage increase. Though this may be only a theoretical case.) A more pronounced effect is expected in the case of smaller firms.

The drop in asset values due to unfavourable monetary changes or crisis increases leverage, generating agency conflicts between lenders and owners of a firm (Jensen - Meckling, 1976; Holmström - Tirole, 1996). However, the balance sheet multiplier channel leaves debt unchanged; leverage is expected to remain unchanged or decline. The balance sheet multiplier effect may have a greater impact on firms with less collateral, i.e. firms of smaller size.

Summarizing the above findings, the tight monetary conditions or crises have a negative effect on leverage through every channel of the monetary transmission; leverage declines or remains unchanged, if equity decreases with the same rate as debt. Taking corporate characteristics into account, it is expected that unfavorable monetary policy or crises will have a more pronounced effect on leverage in case of smaller size and/or non-listed status. 


\section{Development of financing mix}

The bank credit channel works towards the decrease in bank credit position of the firm, while the bond and equity position may rise or remain unchanged, depending on the access to financing sources. In case of larger and/or listed firms, alternative sources may substitute the tightening supply of bank credit (Leary, 2009). The development of a cash position is questionable; a decrease may occur since firms are utilizing their savings due to them running short on bank credit, though a cash hoarding strategy is also conceivable when expecting further tightening of credit supply, and a deepening of the crisis (Kahle - Stulz, 2013).

Unfavorable monetary conditions, working through the credit supply channel may cut back bank credit position, bond and equity issuances. The flight to quality phenomena of the markets hinders and makes issuances expensive, for larger and/or listed companies as well. The development of a cash position is questionable. The hoarding strategy may be justified by current risky operations and by the expectation of a further deepening of the crisis.

The falling demand, exerting its effect through the demand channel, makes assets less valuable, their secondary market struggling, resulting in a falling value of net worth and in strengthening credit conditions. A fall in demand may also turn the firm's profitability into negative, impairing access to financing, the fulfillment of debt service and covenants, the renewal of existing credit lines, the borrowing of new credit, and the financing by alternative sources in general. Further, falling profitability hinders the cash hoarding. These factors have a more pronounced effect on firms of smaller size, mainly due to their low level of diversification.
The balance sheet multiplier channel works towards a decrease in the net worth and asset value of the firm, which leads to an increasing leverage. The higher level of leverage may cause debt overhang, where the existing debt position turns out to be riskier and not only debt, but also equity issuance becomes more hindered (Myers, 1977). The multiplier channel may have a more significant effect on the financing mix of smaller companies under tight monetary conditions than on that of larger firms.

In summary, the following statements can be made: Tight monetary conditions, crises have a negative impact on the bank credit position through every channel of monetary transmission. The position decreases irrespective of corporate characteristics like size and listed status.

Bond and equity issuance may increase considering the bank credit channel in case of larger and/or listed companies, but considering the credit supply channel, there is no expectation that the tightening bank credit supply may be substituted by alternative sources, both in the case of larger and/or listed companies.

The development of cash position may be evaluated based on the functioning of the demand channel; cash hoarding is hindered by falling demand and falling profitability. This phenomenon may affect larger companies less due to their more diversified operations.

(The findings on the expected development of capital structure in tight monetary conditions and crisis considering the monetary transmission channels and access to external financing are summarized and shown in Table 1.)

Table 1

The expected development of corporate capital structure in tight monetary conditions and crisis
considering the monetary transmission channels and access to external financing

\begin{tabular}{|c|c|c|c|c|c|c|c|c|}
\hline \multirow{3}{*}{$\begin{array}{l}\text { Leverage and } \\
\text { financing mix } \\
\text { elements }\end{array}$} & \multicolumn{2}{|c|}{$\begin{array}{c}\text { Bank credit chan- } \\
\text { nel }\end{array}$} & \multicolumn{2}{|c|}{ Credit channel } & \multicolumn{2}{|c|}{ Demand channel } & \multicolumn{2}{|c|}{$\begin{array}{c}\text { Balance sheet multipli- } \\
\text { er effect }\end{array}$} \\
\hline & \multicolumn{2}{|c|}{$\begin{array}{l}\text { Access to external } \\
\text { financing is }\end{array}$} & \multicolumn{2}{|c|}{$\begin{array}{l}\text { Access to external } \\
\text { financing is }\end{array}$} & \multicolumn{2}{|c|}{$\begin{array}{l}\text { Access to external } \\
\text { financing is }\end{array}$} & \multicolumn{2}{|c|}{$\begin{array}{c}\text { Access to external fi- } \\
\text { nancing is }\end{array}$} \\
\hline & imp. & not imp. & imp. & not imp. & imp. & not imp. & imp. & not imp. \\
\hline Leverage & -- & $-/ 0$ & - & $-/ 0$ & 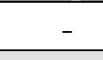 & $-/ 0$ & -- & $-/ 0$ \\
\hline $\begin{array}{c}\text { Internal financing } \\
\text { sources }\end{array}$ & $-/+$ & $-/+$ & $-/+$ & $-/+$ & -- & $-/ 0$ & NA & NA \\
\hline Equity issuance & 0 & + & - & - & -- & - & - & $-/ 0$ \\
\hline Bond issuance & 0 & + & - & - & -- & - & - & $-/ 0$ \\
\hline Bank financing & - & - & - & - & -- & - & - & $-/ 0$ \\
\hline Trade credit & $-/+$ & $-/+$ & $-1+$ & $-1+$ & $-/+$ & $-/+$ & $-1+$ & $-1+$ \\
\hline
\end{tabular}

Abbreviations: imp. impaired; not imp. not impaired; + increase; - decrease; -- large decrease; 0 no change; NA course of change is not predictable 


\section{Development of trade credit}

Trade credit shows some peculiarities among the financing mix elements. In order to assess the expected development of trade credit during tight monetary conditions, crisis, a short review of theories on usage of trade credit is necessary.

There are two main theories about the utilization of trade credit (for a detailed literature review of trade credit find Petersen - Rajan, 1997).

The transaction cost theory describes, that trade credit may provide a way of economising on cash usage and its costs. Trade credit reduces the payment and administration costs between trade parties, e.g. by cumulating obligations for longer payment periods, by smoothing out seasonalities or uncertainties in the demand for the products and goods (Ferris, 1981; Laffer, 1970 in Kohler - Britton - Yates, 2000).

The financing theory of trade credit exploits the financing advantage of suppliers over intermediated credit providers. Advantages result from three main specialities of supplier-buyer relationship based on Schwartz (1974). Suppliers have an information advantage by acquiring direct and more precise information on the credit-worthiness of a buyer by means of the size and timing of orders, the ability to take advantage of early-payment discounts, etc.). Suppliers also have an advantage in monitoring and enforcing repayment, if necessary. Moreover, the products may act as a kind of collateral for the suppliers, since they have an advantage in finding a secondary market and in selling the repossessed products, goods.

Trade credit may have a substitutional or a complementary role to intermediated financing in the financing mix. The offsetting of a substitutional role, i.e. the functioning of a "trade credit channel" when intermediated credit is scarce and the credit and/or bank credit channels tighten, is enabled by the assumption, that in tightening, crisis the cost of finance raises less for providers of trade credit with direct access to capital markets, than the external finance premium for firms dependent on intermediated credit. A complementary role is also justified, when intermediated credit received signals the creditworthiness of the firm. In monetary tightening, crisis, the decreasing financing by intermediated credit cannot get substituted by trade credit, since trade credit is not supplied due to the lack of creditworthiness.

The development of trade credit usage is scarcely investigated; there is not any complex theoretical framework elaborated for assessing the impact of tight monetary conditions, crises on trade credit usage considering the transmission channels. The functioning of a trade credit channel, but also a complementary role of trade credit usage is justified.

\section{Empirical results on the impact of tight monetary conditions and crises on corporate capital structure}

Although based on the findings of a few studies, tight monetary conditions or crises seem to have no effect on corporate capital structure (Akbar - Rehman - Ormrod, 2013 in the case of 1/t financing; Lemmon - Roberts, 2010), the vast majority of studies evidence the relationship. In the following, empirical literature on the impact of monetary policy and crisis on the development of corporate capital structure is reviewed, also referring to the access to external financing. Empirical results for the CEE region are also highlighted; the intention herewith is to investigate if the region's uniqueness has an impact on the investigated relationship.

\section{Firms with impaired access to external financing}

Capital structure development of firms with limited access to financing has scarcely been investigated. Concerning leverage, a decrease is evidenced by the majority of studies (Leary, 2009; Iyer et al., 2013; Szemán, 2013; Demirguc-Kunt - Martinez-Peria - Tresse, 2015), though the increase in leverage is stated by Mostarac Petrovic (2013).

Existing studies emphasize the importance of internal financing sources (Campello - Graham - Harvey, 2010; Campello et al., 2011a; Campello et al., 2011b; Leary, 2009; Akbar - Rehman - Ormrod, 2013; Iyer et al., 2013) and the missing substitution of decreasing bank supply by alternative sources in tight monetary conditions (Leary, 2009; Akbar - Rehman - Ormrod, 2013; Iyer et al., 2013; Harrison - Widjaja, 2013).

Campello, Graham and Harvey (2010), Campello et al. (2011a) and Campello et al. (2011b) state that the 2007/08 crisis hindered, but did not cut back fully, the utilization of credit lines. Though whether a firm has impaired access or not is defined by the CFO's subjective opinion, the results support the pecking order theory, since not only firms with impaired access, but also those with access to financing, i.e. also profitable and liquid firms prefer internal to external financing. Leary (2009) states that the leverage and bank credit position of smaller, bank dependent firms decreased, while internal financing increased significantly during the credit crisis in 1966. Akbar, Rehman and Ormrod (2013) studied the sample of UK private companies in 2007-2009. They find that the tightening of the supply side had the greatest negative effect on the short financing channels, i.e. $\mathrm{s} / \mathrm{t}$ bank credit, trade credit. Furthermore, cash and equity issuance increased, while substitution by net debt issuance and trade credit was not prevalent. Iyer et al. (2013) find that the Portuguese corporate sector was hit in diverse manners by the drop in bank financing during the 2007/08 crisis. Smaller, 
younger firms, and firms with weaker bank relationships suffered more from the tightening of the bank credit supply. Substitution by alternative sources did not take place independently from firm size.

The role of trade credit under unfavorable monetary conditions is rarely investigated. Its substitutional and supplementary role is also reasonable. Petersen and Rajan (1996) confirm the substitutional role of trade credit, mainly in the case of firms with impaired access to financing. Though they also emphasize that trade credit may signal the quality of a firm, reducing the adverse selection, and resulting in the increase of leverage. This latter highlights the supplementary role of trade credit. Akbar, Rehman and Ormrod (2013) and Love and Zaidi (2010) state the supplementary role in case of firms with impaired access to financing.

\section{Firms with access to external financing}

The positive development of leverage is evidenced by the majority of studies (Iqbal - Kume, 2014; Fosberg, 2012 and 2013; Voutsinas - Werner, 2011), while a decrease in leverage is stated by Demirguc-Kunt, Martinez-Peria and Tresse (2015).

The importance of internal sources during unfavorable monetary conditions in the case of listed companies is highlighted by Kim, Heshmati and Aoun (2006), Voutsinas and Werner (2011) and by Harrison and Widjaja (2013). Kim, Heshmati and Aoun (2006) state having had a preference for internal financing sources during the Asian crisis, primarily for profitable firms with growth opportunities, while Voutsinas and Werner (2011) find that internal sources substituted, while alternative external sources did not replace, the shrinking bank credit for listed companies during the Japanese crisis in 1998. Harrison and Widjaja (2013) also underline the importance of internal sources for S\&P 500 companies during the 2007/08 crisis.

Fosberg (2012 and 2013) find falling debt and equity issuance for listed US companies during the 2007/08 crisis. Specifically for $s / t$ financing, a remarkable growth was observed by Fosberg (2013); the reason for this lies in the overcoming of a decrease in trade finance, $1 / \mathrm{t}$ credits and equity-type financing by $\mathrm{s} / \mathrm{t}$ credits. However, according to the results of Pattani, Vera and Wackett (2011), Kahle and Stulz (2013) and Iqbal and Kume (2014), firms with access to external financing have significantly financed their operations from the bond and equity market during the crisis. Results based on the studies of Becker and Ivashina (2014) and Adrian, Colla and Shin (2012) examining companies with bond market access, also state the substitution of falling bank credit supply through bond issuance. Concerning debt issuance, an important finding is that of Kahle and Stulz (2013). They doubt that the 2007/08 crisis had any impact on capital structure through the bank lending channel. They find that there was no larger fall in debt issuance observable in the case of bank dependent firms, as in the case of non-dependent firms.

Referring to the development of cash position, Kahle and Stulz (2013) surprisingly find that bank dependent firms hoarded cash to a greater extent than non-dependent firms during crisis.

Trade credit has a substituting role in case of large, listed companies during the Asian crisis (Love - Preve - Sarria-Allende, 2007) and during the Japanese bank credit crisis (Voutsinas - Werner, 2011), though a supplementary role is found for total financing (Voutsinas - Werner, 2011).

\section{Empirical results for the CEE region}

Analyzing the supply side of the development of capital structure, Ongena, Schindele and Vonnák (2014) deliver an interesting result, stating that a lower domestic interest rate expands the credit supply only in local currencies. Domestic supply of credit in foreign currencies blocks the transmission of local monetary policy through the bank lending channel only in case of local currency.

Mörec and Raskovic (2011) find, that the Slovenian corporate sector suffered from the fall in credit supply during the 2007/08 crisis. Larger firms though managed to lower their demand for financing by decreasing the level of inventories, but the SMEs did not find any viable solution for their lack of finance. Szemán (2013) also finds a fall in external financing during the crisis. Studying the capital structure development of the Hungarian corporate sector, Szemán (2013) states that the share of total liabilities fell during the crisis, though the fall was only immediate in the case of the $s / t$ debt. Rusu and Toderascu (2014) verify the fall in bank liabilities by examining datas from seven CEE countries.

However, Mostarac and Petrovic (2013) find that the leverage of Croatian companies increased, mainly through the increase of $\mathrm{s} / \mathrm{t}$ debt.

The substitutional role of trade credit cannot be verified by Szemán (2013).

The empirical results are summarized and shown in Table 2.

\section{Lessons learned about the impact of tight monetary conditions, crisis on corporate capital structure}

This study contributes to the extant literature on corporate capital structure by setting a framework for analyzing the relationship of monetary conditions and capital structure, and by identifying the lessons learned and open research areas of the topic investigated as follows. 
The expected development of corporate capital structure in tight monetary conditions and crisis considering the monetary transmission channels and access to external financing

\begin{tabular}{|c|c|c|}
\hline \multirow[b]{2}{*}{$\begin{array}{l}\text { Change in leverage and } \\
\text { financing mix elements }\end{array}$} & \multicolumn{2}{|l|}{ Firms investigated have } \\
\hline & $\begin{array}{l}\text { impaired access } \\
\text { to external financing }\end{array}$ & $\begin{array}{l}\text { access } \\
\text { to external financing }\end{array}$ \\
\hline Leverage increases & Mostarac and Petrovic (2013) & $\begin{array}{l}\text { Iqbal and Kume (2014) } \\
\text { Fosberg (2012) } \\
\text { Fosberg (2013) } \\
\text { Voutsinas and Werner (2011) }\end{array}$ \\
\hline Leverage decreases & $\begin{array}{l}\text { Leary (2009) } \\
\text { Iyer et al (2013) } \\
\text { Szemán (2013) } \\
\text { Demirguc-Kunt, Martinez-Peria and } \\
\text { Tresse (2015) }\end{array}$ & $\begin{array}{l}\text { Demirguc-Kunt, Martinez-Peria and } \\
\text { Tresse (2015) }\end{array}$ \\
\hline Bank credit increases & & $\begin{array}{l}\text { Fosberg (2013) - s/t; } \\
\text { Iqbal and Kume (2014) }\end{array}$ \\
\hline Bank credit decreases & $\begin{array}{l}\text { Leary (2009) } \\
\text { Pattani,Vera and Wackett (2011) } \\
\text { Iyer et al (2013) } \\
\text { Mörec and Raskovic (2011) } \\
\end{array}$ & $\begin{array}{l}\text { Pattani, Vera and Wackett (2011) } \\
\text { Adrian, Colla and Shin (2012) } \\
\text { Becker and Ivashina (2014) } \\
\text { Rusu and Toderascu (2014) }\end{array}$ \\
\hline $\begin{array}{l}\text { Use of internal sources } \\
\text { increases }\end{array}$ & $\begin{array}{l}\text { Leary (2009) } \\
\text { Lin and Paravisini (2010) Campel- } \\
\text { lo,Graham,Harvey(2010) } \\
\text { Campello et al. (2011a) } \\
\text { Campello et al. (2011b) } \\
\text { Akbar, Rehman, Ormrod (2013) }\end{array}$ & $\begin{array}{l}\text { Kim et al (2006) } \\
\text { Campello,Graham, Harvey (2010) } \\
\text { Campello et al. (2011a) } \\
\text { Campello et al. (2011b) } \\
\text { Voutsinas and Werner (2011) } \\
\text { Harrison and Widjaja (2013) }\end{array}$ \\
\hline Bond issuance increases & & $\begin{array}{l}\text { Pattani, Vera and Wackett (2011) } \\
\text { Adrian, Colla and Shin (2012) } \\
\text { Becker and Ivashina (2014) } \\
\text { Kahle and Stulz (2013) }\end{array}$ \\
\hline Bond issuance decreases & & Fosberg (2012) \\
\hline Equity issuance increases & & Pattani, Vera and Wackett (2011) \\
\hline Equity issuance decreases & & $\begin{array}{l}\text { Fosberg (2012) } \\
\text { Fosberg (2013) }\end{array}$ \\
\hline Trade credit increases & & $\begin{array}{l}\text { Voutsinas and Werner (2011) } \\
\text { Love et al (2007) }\end{array}$ \\
\hline $\begin{array}{l}\text { Trade credit is unchanged or } \\
\text { decreases }\end{array}$ & $\begin{array}{l}\text { Akbar, Rehman, Ormrod (2013) } \\
\text { Love and Zaidi (2010) } \\
\text { Szemán (2013) }\end{array}$ & \\
\hline
\end{tabular}

I. Though the relation of tight monetary conditions and capital structure is examined by several studies (Gertler-Gilchrist, 1993 and 1994; Oliner-Rudebusch, 1995; Bernanke - Gertler - Gilchrist, 1996; Kashyap Stein - Wilcox, 1993; Kashyap - Stein, 2000), the analysis of crisis is scarce, especially the $2007 / 08$ crisis is not investigated throughoutly.

II. The majority of the studies analyzing the impact of crisis take the data of large, listed companies, i.e. that of firms with access to external financing (e.g. Iqbal -
Kume, 2014; Fosberg, 2012 and 2013; Harrison - Widjaja, 2013). There is a clear lack of studies involving smaller, non-listed companies.

III. In spite of the increasing number of analyses, we do not have a common understanding on the effect of the tight monetary conditions, crisis on corporate capital structure. The results are conflicting; the theoretical and empirical results do not build a coherent system.

IV. There is a conspicuous difference in case of the development of leverage. Expected decrease of lever- 
age is stated by a few studies (Leary, 2009; Iyer et al., 2013; Szemán, 2013; Demirguc-Kunt - Martinez-Peria - Tresse, 2015), but there are also results on increasing leverage levels, especially in case of listed and/or firms of bigger size, e.g. in case of not impaired access to external financing (Iqbal - Kume, 2014; Fosberg, 2012; Fosberg, 2013; Voutsinas - Werner, 2011). Though the opposite relations are also evidenced; increasing leverage in case of firms with impaired access (Mostarac Petrovic, 2013) and decreasing leverage for large and/or listed firms (Demirguc-Kunt - Martinez-Peria - Tresse, 2015).

V. The evolution of financing mix elements has not been researched comprehensively. A clear statement cannot be made regarding their development as a result of supply side effects.

- The decreasing level of bank credit financing is stated by empirical results, independently from type of access to external financing (e.g. Leary, 2009; Pattani - Vera - Wackett, 2013; Becker Ivashina, 2014). Although there are some evidence for firms with external financing sources on increasing bank financing in crisis time (Fosberg, 2013; Iqbal - Kume, 2014).

- There is no clear evidence on the increase in importance of financing by bond and equity issuances as a result of tight monetary periods, crisis. However the increasing bond and equity issuance is evidenced by several studies (e.g. Pattani - Vera - Wackett 2011; Kahle - Stulz, 2013), Fosberg (2012) and Fosberg (2013) report adverse results.

- Further, there is a lack of evidence on the evolution of bond and equity issuances in case of firms with impaired access to external financing sources.

- Trade credit's substitutional role for large, listed companies for $\mathrm{s} / \mathrm{t}$ financing is verified by several studies (Love - Preve - Sarria-Allende, 2007; Voutsinas - Werner, 2011), though a supplementary role cannot get stated for total financing (Voutsinas - Werner, 2011) and in case of firms with impaired access (Akbar - Rehman - Ormrod, 2013; Love - Zaidi, 2010; Szemán, 2013).

- The increase in usage of internal financing sources is declared for both type of firms (e.g. Lin - Paravisini, 2010; Kim - Heshmati - Aoun, 2006; Voutsinas - Werner, 2011).

VI. The implication for future empirical research in the area involving smaller and/or private companies, i.e. companies with impaired access to external financing, is set. The evolution of capital structure components, i.e. that of leverage and financing mix elements, has to be examined further in order to construct a clear picture of the role of supply factors and monetary policy in shaping capital structure. A special need for clean results in the case of the CEE region is also obvious.

\section{References}

Adrian, T. - Colla - Shin, H. S. (2012): Which Financial Frictions? Parsing the Evidence from the Financial Crisis of 2007-9. (On-line). National Bureau of Economic Research, Working Paper 3487. Cambridge, Available from http//www.nber.org/papers/w18335, (Accessed 25 May 2015)

Akbar, S. - Rehman, S. - Ormrod, P. (2013): The impact of recent financial shocks on the financing and investment policies of UK private firms. International Review of Financial Analysis, 26: p. 59-70.

Becker, B. - Ivashina, V. (2014): Cyclicality of credit supply Firm level evidence. Journal of Monetary Economics, 62: p. 76-93.

Berger, A. - Udell, G. (2002): Small business credit availability and relationship lending. The importance of bank organisational structure. The Economic Journal, 112 (477): p. 32-53.

Bernanke, B. - Blinder, A. (1988): Credit, Money, and Aggregate Demand. (On-line). National Bureau of Economic Research, Working Paper 2534. Cambridge, Available from http//www.nber.org/papers/ w2534, (Accessed 22 May 2015)

Bernanke, B. - Blinder, A. (1990): The Federal Funds Rate and the Channels of Monetary Transmission. (On-line). National Bureau of Economic Research, Working Paper 3487. Cambridge, Available from http//www.nber.org/papers/w3487, (Accessed 22 May 2015)

Bernanke, B. - Gertler, M. - Gilchrist, S. (1996): The Financial Accelerator and the Flight to Quality. The Review of Economics and Statistics, 78 (1): p. 1-15.

Blinder, A. - Stiglitz, J. (1983): Money, Credit Constraints, and Economic Activity. (On-line). National Bureau of Economic Research, Working Paper 1084. Cambridge, Available from http//www.nber. org/papers/w1084, (Accessed 22 May 2015)

Brunnermeier, M. - Oehmke, M. (2012): Bubbles, Financial Crises, and Systemic Risk. (On-line). National Bureau of Economic Research, Working Paper 18398. Cambridge, Available from http//www. nber.org/papers/w18398, (Accessed 22 May 2015)

Campello, M. - Graham, J. - Harvey, C. (2010): The real effects of financial constraints Evidence from a financial crisis. Journal of Financial Economics, 97 (3): p. 470-487.

Campello, M. - Giambona, E. - Graham, J. - Harvey, C. (2011a): Liquidity Management and Corporate Investment During a Financial Crisis. Review of Financial Studies, 24 (6): p. 1944-1979. 
Campello, M. - Giambona, E. - Graham, J. - Harvey, $C$. (2011b): Access to Liquidity and Corporate Investment in Europe during the Financial Crisis. Review of Finance, 16 (2): p. 323-346.

Demirguc-Kunt, A. - Martinez-Peria, M. A. - Tresse, T. (2015): The Impact of the Global Financial Crisis on Firms' Capital Structure. Policy Research working paper; no. WPS 7522. Washington, D.C.: World Bank Group. (On-line). Available from http://documents.worldbank.org/curated/en/2015/12/25705513/ impact-global-financial-crisis-firms-capital-structure, (Accessed $1^{\text {st }}$ February, 2016)

Duchin, R. - Ozbas, O. - Sensoy, B. (2010): Costly external finance, corporate investment, and the subprime mortgage credit crisis. Journal of Financial Economics. 97 (3): p. 418-435.

Faulkender, M. - Petersen, M. (2006): Does the Source of Capital Affect Capital Structure? Review of Financial Studies. 19 (1): p. 45-79.

Fosberg, R. (2012): Capital structure in the financial crisis. Journal of Finance and Accountancy. (Online) Available from http//www.aabri.com/manuscripts/121213.pdf, (Accessed 20 May 2015)

Fosberg, R. (2013): Short-Term Debt Financing During the Financial Crisis. International Journal of Business and Social Science, 4 (8), (On-line). Available from http//ijbssnet.com/journals/Vol_4_No_8_Special_Issue_July_2013/1.pdf, (Accessed 20 May 2015)

Gertler, M. - Gilchrist, S. (1993): The Role of Credit Market Imperfections in the Monetary Transmission Mechanism Arguments and Evidence. The Scandinavian Journal of Economics, 95 (1): p. 43-64.

Gertler, M. - Gilchrist, S. (1994): Monetary Policy, Business Cycles, and the Behavior of Small Manufacturing Firms. The Quarterly Journal of Economics, 109 (2): p. 309-340.

Hancock, D. - Wilcox, J. (1998): The "credit crunch" and the availability of credit to small business. Journal of Banking and Finance, 22 (6-8): p. 983-1014.

Harrison, B. - Widjaja, T. (2013): Did the financial crisis impact on the capital structure of firms? (Online). Discussion papers in economics. Nottingham Trent University. Available from https//www.ntu. ac.uk/nbs/document_uploads/151944.pdf , (Accessed 22 May 2015)

Holmström, B. - Tirole, J. (1996): Private and Public Supply of Liquidity. (On-line). National Bureau of Economic Research, Working Paper 5817. Cambridge, Available from http//www.nber.org/papers/ w5817, (Accessed 22 May 2015)

Iqbal, A. - Kume, O. (2014): Impact of Financial Crisis on Firms' Capital Structure in UK, France, and Germany. Multinational Finance Journal, 18 (18): p. 249-280.
Iyer, R. - Lopes, S. - Peydró, J. - Schoar, A. (2013): Interbank Liquidity Crunch and the Firm Credit Crunch Evidence from the 2007-2009 Crisis. Review of Financial Studies, 27 (1): p. 347-372.

Kahle, K. M. - Stulz, R. M. (2013): Access to capital, investment, and the financial crisis. Journal of Financial Economics, 110 (2): p. 280-299.

Kashyap, A. - Stein, J. - Wilcox, D. (1993): Monetary Policy and Credit Conditions Evidence From the Composition of External Finance. American Economic Review, 83 (1): p. 78-98.

Kashyap, A. - Stein, J. (2000): What Do a Million Observations on Banks Say About the Transmission of Monetary Policy? American Economic Review, 90 (3): p. 407-428.

Khwaja, A. I. - Mian, A. (2008): Tracing the Impact of Bank Liquidity Shocks Evidence from an Emerging Market. American Economic Review, 98 (4): p. 1413-1442.

Kim, H. - Heshmati, A. - Aoun, D. (2006): Dynamics of Capital Structure: The Case of Korean Listed Manufacturing Companies. Asian Economic Journal, 20 (3): p. 275-302.

Kohler, M. - Britton, E. - Yates, A. (2000): Trade credit and the monetary transmission mechanism. The Bank of England Working Paper No. 115. Available from http://www.bankofengland.co.uk/archive/Documents/historicpubs/workingpapers/2000/wp115. pdf (Accessed 3rd February 2015)

Leary, M. T. (2009): Bank Loan Supply, Lender Choice, and Corporate Capital Structure. The Journal of Finance, 64 (3): p. 1143-1185.

Lemmon, M. - Roberts, M. R. (2010): The Response of Corporate Financing and Investment to Changes in the Supply of Credit. Journal of Financial and Quantitative Analysis, 45 (3): p. 555-597.

Love, I. - Zaidi, R. (2010): Trade Credit, Bank Credit and Financial Crisis. International Review of Finance, 10 (1): p. 125-147.

Michaelas, N. - Chittenden, F. - Poutziouris, P. (1999): Financial Policy and Capital Structure Choice in U.K. SMEs Empirical Evidence from Company Panel Data. Small Business Economics, 12 (2): p. 113-130.

Modigliani, F. - Miller, M. H. (1958): The cost of capital, corporate finance and the theory of investment. American Economic Review, 48: p. 261-297.

Mörec, B. - Raskovic, M. (2011): Overview and estimation of the 2008 financial and economic crisis 'effect size' on SME capital structures case of Slovenia. Ekonomska Istraživanja, 24 (4): p. 107-125. Preliminary paper.

Mostarac, E. - Petrovic, S. (2013): Determinants of capital structure of Croatian enterprises before and during the financial crisis. (On-line). UTMS Journal of 
Economics, 4 (2): p. 153-162. Available from http// utmsjoe.mk/files/Vol.\%204\%20No.\%202/B8_-_Mostarac_-_Petrovic.pdf, (Accessed 7 June 2015)

Myers, S. C. (1977): Determinants of corporate borrowing. Journal of Financial Economics, 5 (3): p. 147-175.

Oliner, S. D. - Rudebusch, G. D. (1995): Is there a broad credit channel for monetary policy? (On-line). Economic Review. Federal Reserve Bank of San Francisco: p. 3-13. Available from http//www.frbsf. org/econrsrch/econrev/96-1/3-13.pdf, (Accessed 3 February 2015)

Ongena, S. - Schindele, I. - Vonnák, Dzs. (2014): In lands of foreign currency credit, bank lending channels run through? The effects of monetary policy at home and abroad on the currency denomination of the supply of credit. Budapest: Institute of Economics, Centre for Economic and Regional Studies, Hungarian Academy of Sciences. No. MT-DP 2014/24. (Online). Available from http://econ.core. hu/file/download/mtdp/MTDP1424.pdf, (Accessed $1^{\text {st }}$ February, 2016)

Paravisini, D. (2007): Local Bank Financial Constraints and Firm Access to External Finance. The Journal of Finance, 63 (5): p. 2161-2193.

Pattani, A. - Vera, G. - Wackett, J. (2011): Going Public UK Companies' Use of Capital Markets. (On- line). Bank of England Quarterly Bulletin, Q4, 2011. Available from http//ssrn.com/abstract=1979388, (Accessed 23 May 2015)

Petersen, M. A. - Rajan, R. G. (1997): Trade credit: theories and evidence. Review of Financial Studies. 10 (3): p. 661-691.

Romer, C. D. - Romer, D. H. (1989): Does Monetary Policy Matter? A New Test in the Spirit of Friedman and Schwartz. (On-line) National Bureau of Economic Research, Working Paper 2966. Cambridge, Available from http//www.nber.org/papers/w2966, (Accessed 2 July 2015)

Rusu, V. - Toderascu, C. (2014): Enterprise Financing in the Context of Macroeconomic Instability. Evidence from CEE Countries. Procedia Economics and Finance, 15: p. 730-737.

Schwartz, R. A. (1974): An economic model of trade credit. Journal of Financial and Quantitative Analysis, 9 (4): p. 643-657.

Szemán J. (2013): A pénzügyi válság hatása a magyar vállalatok tôkeszerkezetére. Ekonomické štúdie teória a prax: p. 136-146.

Voutsinas, K. - Werner, R. (2011): Credit supply and corporate capital structure Evidence from Japan. International Review of Financial Analysis, 20 (5): p. 320-334. 